\title{
Study on Classification and Characteristics of Gansu- Tibetan Long Narrative Folk Poems
}

\author{
Zejia Zhuo \\ Northwest Minzu University \\ Lanzhou, China
}

\begin{abstract}
The Tibetan people living in the snow-covered Tibetan Plateau are born to have poetic talents, which have empowered them to create many valuable long narrative folk poems. Most of the poems are widespread in Amdo Tibetan Region which is a central inhabited region for Tibetan people in Gansu and Tibet province. Till now, those twisted-plot, vividly depicted and highly region characterized ballads are still loved and sung by Tibetan people living in Amdo. This article uses a combined research method of filed investigation and text analysis to study the classification and characteristics of GansuTibetan long narrative folk poems.
\end{abstract}

Keywords-Gansu Tibetan nationality; long narrative folk poem; classification; characteristics

\section{INTRODUCTION}

Folk poetry is generally divided into folk narrative poems and folk lyric poems. Folk narrative poem is the long narrative song of folk poetry, and also the long oral metrical story collectively created by and spread among folks. Therefore, folk narrative poem is often referred to as "story poem" or "story song". There is a big difference between long folk narrative poems and short folk lyric songs; folk songs are generally of short length, focusing on the direct expression of emotions. Relatively, long folk narrative poems are normally of long length, to indirectly express people's inner feelings by describing and shaping specific characters in a relatively complete story plot, with a greatly impressive poetic language. In terms of the features of the carrier, epic poems and long folk narrative poems both belong to folk narrative poems. They both have complete story plots and typical characters, and all use the language form of verse or verse alternating with prose. However, the two kinds of poems have fundamental differences. Epic poem was born in the childhood of human beings, reflecting human's early social life; generally, long folk narrative poem was produced in the class society, naturally reflecting the class social life. Therefore, the historical time they were born and the contents they expressed are quite different. As a multi-ethnic country, China has many nationalities and ethnic groups that are spreading their own distinctive long narrative poems. These narrative poems together constitute China's colorful gallery of narrative poems.

This paper is from Compilation of Gansu-Tibetan Folk Literature Documents, "2015-2016 Scientific Research Project" of Center for Studies on Literature of Ethnic Minorities in Northwest China. (Project number: XBM2015006X)

\section{GENERAL SITUATION}

Living in the snow-covered plateau, Tibetan people are born with a sense of poetry, so they have created a lot of precious long folk narrative poems. Among those poems, most poems were concentratedly spread in Anduo Area which is centered by Tibetan communities in Gansu and Qinghai. In the area, Tibetan people love those lively story songs with unique regional features, and spread them by singing them everywhere. In Gansu Province, this kind of long folk narrative poems are mainly spread in Hezuo City, Xiahe County, Luqu County and Maqu County located in Gannan Tibetan Autonomous Prefecture on the border between Gansu and Qinghai. In addition, a small part of them are spread in Diebu County and Zhuoni County of Ganan, as well as Tianzhu Tibetan Autonomous County located in the southwest of Wuwei City. These popular long folk narrative poems not only express the feelings and ideals of Tibetan people, but also reflect socio-economic system, ethical concepts, moral ideals, religious concepts and customs in specific areas, which have been formed by history. Therefore, those poems are of multiple academic value. Up to now, the author has collected more than 50 Tibetan long folk narrative poems in Gansu Province. Among those poems, some are collectively created by local people according to real stories, as well as individually created by local artists vocally spread by local people; some are "foreign" long folk narrative poems spread in the local; a small part of them are created by modern writers vocally spread by people. Although those modern writers adopted a folk narrative way, these works have not been excluded by people. From the form of spreading singing, there are mainly three forms: male and female duet, artist solo, and singing with musical instruments (most are Mandolins). Moreover, the melody of these long folk narrative poems varies with different story contents.

\section{CLASSIFICATION}

Mr. Tong Jinhua has made a classification of Tibetan long narrative poems in his book Tibetan Folk Literature. Long narrative poems with a topic of love and marriage are called "Nuotun" in Anduo Tibetan language, mostly with a tragic ending; the feudal ideas in those poems make them include positive social education factors. The long narrative poems with a topic of resisting the oppression of ruling classes and accusing of the dark old society, are called "Jieba". The long narrative poems to praise the heroes and the nature are called 
"Duiba". (1) Here "Nuotun", "Jieba" and "Duiba" are Tibetan transliteration. In Gansu and among more Tibetan people, long narrative poems about marriage and love are generally named as "rogsa-mthun". Other topics do not have a unified name. The above-mentioned "bash-pa" (Jieba) and "bstod-pa" (Duiba) can be found everywhere in Tibetan folk activities. For example: when the annual horse racing is held, owners of horse or the audience present will generally carry on "rtabshd" in a quite exaggerated way. The contents of "rta-bshd" contain the origin, characteristics, and roles of horses, as well as praises for horses in their sight, in order to wish racing horses an ideal result in the race. Another example: before the civil shooting competition, every party of participants will hold a brief ritual ceremony, and the ritualists will give "mdabstod". The content is about introduction of arrow's origin, characteristics, roles, as well as prays for good luck in the competition by worshiping gods, etc. In addition, there are "bstod-pa" of marriages, "bstod-pa" of Hada (a piece of silk used as a greeting gift), "mda-bstod" of black tents, "mdabstod" of palace and so on. From the contents of them, "bstodpa" and "mda-bstod" mainly express praises for something, or show blessings for someone or collective events. What's more important is that although "bstod-pa" and "mda-bstod" belong to folk poetry, there is no story plots and characters in those poems, and their lengths are shorter than long folk narrative poems. Therefore, we can't classify "bstod-pa" and "mdabstod" into long folk narrative poems, and we can't confuse long folk narrative poems with folk songs. According to the content of those long folk narrative poems spread among Tibetan people and collected by the author, those poems can be divided into the following four categories:

\section{A. Poems of Love and Marriage}

The topic of praising pure love, fighting for the freedom of marriage, and reacting against unreasonable marriage systems and feudal ethical codes is most frequently expressed by various long folk narrative poems, and is also the most impressive topic. (2) Love and marriage is one of the most important topics of Tibetan folk narrative poems. Among them, the most famous and typical one is Danaduo and Hezangke. ${ }^{(3)}$ This story poem narrates the love story of young men and women, which is popular with people in entire Anduo Area. The story was named after the names of villages where the hero and heroine lived. It tells a love story happening on the border of Gansu and Qinghai ${ }^{(4)}$ that Tibetan young man Nima Cairang and young girl Dasang Zhuoma dreamed of freedom of marriage and fought for living together as a happy family under the cruel feudal system, and experienced joy, sorrow,

\footnotetext{
(1) Tong Jinhua. "Tibetan Folk Literature" [M]. Tibet Renmin Publishing House. 1991:13

(2) Nong Xueguan. "Introduction of Folk Literature" [M]. The Ethnic Publishing House. 2005:116.

${ }^{3}$ This long folk narrative poem has many names: it has been named after the male and female characters' names as The Love Song of Nima Cairang \& Dasang Zhuoma; it is also named according to the story context as Love of Sun \& Moon; in addition, it is named after the name of the male character's hometown as Danaduo.

(4) Danaduo is located in Duogua Town, Tongren County, Huangnan Tibetan Autonomous Prefecture of Qinghai Province. This place is bounded on Sangke Village and Zangke Village, in Xiahe County, Gannan Tibetan Autonomous Prefecture of Gansu Province.
}

separation and reunion. At the end of the story, the dead lover of the hero (Nima Cairang) reincarnated into his wife's belly, and turned into a baby boy. He was named Dasang Dunzhu. That made their beautiful dream come true. The story reflects the irrationality of the marriage system in the feudal society and the cruelty of marriage sales, and also shows Tibetan young men and women's strong will for the pursuit of freedom and happiness. The entire content is consistent with not only Tibetan people's aesthetic needs and realistic aspirations, but also the expressing forms of folk literature.

Among Tibetan folks in Gasu and Qinghai, there is another well-received long folk narrative poem called Ganjia Gama and Mancang Caiji. This narrative poem is also surrounded with the topic of love, illustrating the rough love experience of a young girl named Caiji from Mancang Village (located in Tongren County, Huangnan Tibetan Autonomous Prefecture, Qinghai Province) and a young man called Gama from Ganjia Village, (located in Xiahe County, Gannan Tibetan Autonomous Prefecture, Gansu Province. The story took place on the border of Gansu and Qinghai. Hero Gama is a handsome and capable young boy, and Caiji is a beautiful, kind and sensible young girl. Because of the usual grazing together, two young people gradually had feelings on each other, and then fell in love. However, people of Ganjia and people of Mancang always had disputes due to grassland, and people from those two places were usually in the situation of killing each other. Thus, there was no one to support and understand their love. In the helpless situation, they planned to run away together to pursue their happiness. However, before they ran away, Ganjia and Mancang had a large conflict again. During the conflict, the brave Gama was killed by Mancang youth's sword. On hearing of Gama's death, Caiji often cried and felt too sad to live. At last, she believed in Buddhism and decided to release her boyfriend's soul from purgatory, so she cut her dark hair and wore a red cassock. This folk narrative poem directly reflects the modern history of a particular region, but also shows the longing for peace, freedom and happiness of Tibetan young men and women who lost their freedom of marriage.

More long narrative poems of love and marriage include Yixi Zhuoma, At Kangsi Road, Tangluo Guowa, Unfaithful Lama, The Wish of a Couple, Yundan Jiacuo and Cairang Cuomu, Resentment of Sala, Girl's Troubles, The Story of Xiongbai and Bancuo, Nalong Yucuo, Promises, The Miserable Cawarong, The Ancient City Lhasa, Jiasang Longduo Layang and Yingcuo, etc. Their story plots are basically similar but destinies of characters vary a lot. Most of them are ended with tragedies, and some of them express the preciousness and value of love by death.

\section{B. Poems of Ethic Edification}

The idea of ethic edification runs through the entire Tibetan folk literature. It is also a common topic of folk narrative poems in Gansu Tibetan area and the entire Anduo Area. This kind of narrative poem generally takes the life experiences or stories of the hero as clues, to indicate social life's realistic questions of kind or evil, beautiful or ugly, true or false, yes or no, right or wrong and so on; in this kind of poem, the hero will bring ethic edification to his children and 
others by telling his own experiences. Therefore, this kind of poems are of important ethic educational function and practical significance. Gansu Tibetan people also have their own story poem of this kind, and that is Sincere Advice of Yari Asuo. "Yari" is a name of a place located in today's Oula Village, Maqu County, Gannan Tibetan Autonomous Prefecture, Gansu Province. "Asuo" is the name of the hero in this narrative poem. In the interview, we learned that Yari Asuo (? - 1951) was a folk artist who presided over justice, had the courage to help others, restrained the powerful and helped the weak, had a good and deep knowledge, as well as was good at debating. ${ }^{5}$ The well-experienced old man took his own experiences as examples to teach future generations about how to treat people and handle things, and what kind of life goals people should pursue in different stages during their development, etc. The old man also expressed his unique view on politics, and inspired people to pursue civilization, self-love, and collective profit from the view of philosophy.

Among Gansu Tibetan folks, there is also a folk narrative poem called Najie Cailuo. Although it is a narrative poem spread from aother place, it is very popular with local people. Najie Cailuo tells a guy named Najie Cailuo at his 70s enjoyed the former half of his life with great wealth, but suffered from poverty in the latter half, homeless and helpless. Suffering from the world's cold and warmth, Najie Cailuo deeply realized the impermanence of life, and advised people not to indulge in the material life, and promoted respecting old people and caring for young people, to do good turns and accumulate virtue. The author was informed in the field research that Najie Cailuo has been passed on for over 140 years, and Najie Cailuo did existed in history, from today's Jiade Village, Duogua Town, Tongren County. His great granddaughter and her family now still Live in the place. That year, Najie Cailuo vocally spoke out his story and asked a person to write down Najie Cailuo on behalf of him, making himself an example to warn the world. ${ }^{6}$ In 2008, this folk narrative poem was adapted into a 45 -minute TV musical by the Tibetan Channel of Qinghai TV station, which was performed by the form of "playing and singing" popular with Tibetan people. The musical received great affection from many Tibetan people.

Among Tibetan people in Gansu, the long narrative poems that expose the dark domination of feudal serfdom and the hypocrisy of the religion, that guide people how to become a pure person of high morality, and that illustrate the philosophy of life, also include Old Man's Advice, Self-Confession of Yider Gaila, Sincere Suggestion of Zhao Jieben, Angqiu Cailuo, Zhaluo Running Business, Advice of Suna, Advice of Manxiu Jiaori, Advice of Manxiu, Confession of Son-in-Law, etc.

\section{Poems of Class Contradiction}

Class contradiction is one of the great topics of the entire folk literature. Thus, Tibetan folk narrative poems certainly

\footnotetext{
(5) Interviewee: Rangcai Dangzhi (from Maqu County); time of interview: February 25th, 2012; place of interview: Maqu County.

${ }^{(6)}$ Interviewee: Wande Lengzhi (from Longwu Town, Tongren County); time of interview: April 11st, 2013; place of interview: Lanzhou.
}

include poems of this topic. Angri Sangjie is not a local narrative poem produced in the local, but it has been widely spread among Tibetan people in Gansu. During the interview, the author was informed that "Angri" (snang-ra) is a place name, and now it is Angla Town of Jianzha County, Huangnan Tibetan Autonomous Prefecture in Qinghai Province. "Sangjie" is the name of the Angri Tribe leader. The main content of the story happened in the period when the Ma Bufang family ${ }^{(7)}$ ruled Qinghai, and shows the family's cruel oppression to the vast number of Tibetan people, including the Angri Tribe. In the case of knowing that they didn't have any advantage to fight, Angri Tribe leader Sangjie firmly decided to take people to fight with local warlords. During the fight, countless Tibetan people and the three sons of Sangje sacrificed. ${ }^{8}$ The story has enthusiastically praised the spirit that Angri Tribe leader Sangjie led Tibetan people against the enemy and defend their hometown. Also, Kaji Jialuo is also a narrative poem about accusing Ma Bufang army of killing innocent people. The story tells that a few horses of Ma Bufang army were stolen by someone, and the army suspected Kaji Jialuo was the thief. They forcibly took Kaji Jialuo away without any evidence. During that time, no matter how Kaji Jialuo appealed this incident to the local official, the official didn't trust him. In the end, he was killed brutally. This kind of poems exposed the brutalities and atrocities of feudal forces, expressed the Tibetan people's dream of peace, freedom, and happy life. In Gansu and more Tibetan areas, there are still many long narrative poems spread now, which reflect the social truth of the class society. For example: Official of hundreds of Families, Story of Bleeding Milk, The Eldest Son of Acuo Tribe Leader, Lucang Hero, Guzhong and so on. Most of these folk narrative poems are based on major historical events, and the hero of the story is basically an important regional leader or hero in history, which is the reason why these magnificent narrative poems have been constantly spread among folks and are never lost.

\section{Poems of Tragic Life}

This kind of long narrative poems are similar or close to long narrative poems of ethic edification and class contradiction, but this kind of poems are obviously different from those two kinds. Long narrative poems of ethic edification and tragic life both have one hero, all taking personal experiences or stories as clues, but the content of the

\footnotetext{
(7) The ancestors of Northwestern warlords all with last name Ma. Firstly, they took advantage of the inner war of the Taiping Heavenly Kingdom and made an incident in Northwest, which in history was called Shanxi-Gansu Incident of Hu People. Then, they were suppressed by Zuo Tsung-tang and paid allegiance to Qing government, so they participated in the suppression of " $\mathrm{Hu}$ riot" and were all granted titles and money. They successively followed and served many governors, such as Qing government, the Northern Warlords, Chiang Kai-shek, etc. They abided by the recruitment standard of "Gan, He, $\mathrm{Hu}, \mathrm{Ma}$ " (That means they hired Gansu and Hezhou people. "Hezhou people" is the old name to call people from Linxia, Gansu today; before the liberation of China in 1949, Linxia was named as Hezhou. "Hu"and "Ma" represent people with last names of "Hu" and "Ma".), and they followed the rule of son inheriting father's position and younger brother inheriting elder brother's position. After decades of development, they gradually became the armed force of warlords that controlled the situation of Northwest.

(8) Interviewee: Gengsang (from Angla Village, Jianzha County); time of interview: March 4th , 2012; place of interview: Lanzhou.
} 
former is generally about ethical education, while the latter is mainly about describing varies of tragic stories of life. However, this kind of tragic personal destiny is inseparable from the root of class contradiction, but long narrative poems of tragic life don't reflect the spirit of resistance under class oppression. Therefore, this kind of poems about tragic life certainly has some differences from the narrative poems of class contradiction mentioned above. Surely, due to the particularity of the time poems were produced, all narrative poems, to different degrees, are related to class contradiction. For example, Sad Song of Orphan tells an orphan who lost his loved ones at an early age. The lonely and homeless orphan suffered all kinds of ignorance and frustration in the world, and he never tried to change his destiny. Finally, he died under the ridicule and accusation of others. Girl Lari tells a girl named Lari was "sold" by her parents to a guy she never knew, and she was cruelly abused and tortured by her husband and her mother-in-law. In contrast, the number of this kind of narrative poems is less, and their length is shorter than those three kinds mentioned above.

\section{CHARACTERISTICS}

\section{A. Single-Line Progressive Structural Mode}

Most long folk narrative poems are of similar structural features, and almost use single-line progressive structural mode, whether their complete story plots are complicated or not. That is to say those stories take the leading characters' stories as major clues, and the stories develop and move forwards by a single-line order; sometimes they use expression methods of flashback or narration interspersed with flashback, but not frequently. In addition, long folk narrative poems, during the entire long development, have gradually formed a set of patterns. That is to say that every complete long narrative poem basically has a prelude song or primer at the beginning of the story, followed by the beginning, the development, the climax, the ending, and the final of the story. Looking at Gansu's and the entire Tibetan long folk narrative poems, they all have the structural characteristics mentioned above. Take the love story poem Danado and Hezangke for example, which includes nine parts as followings: (1) the prelude song; (2) determination of their affection to each other; (3) pledge of love; (4) meeting up; (5) death (heroine); (6) seeking for death (hero); (7) looking for lover's bones; (8) recalling memories; (9) the end. The prelude song part has completely introduced the characters of the story, and " determination of their affection to each other" and "pledge of love" are respectively the beginning and the development parts of the story, introducing the status of the hero and the heroine. From the "meeting up" to "looking for lover's bones", there has been the climax part of the story. This part has described the rough love experience and the personalities of Nima Cairang and Dasang Zhuoma in a way of narrative combining with lyric, and it has pushed the story towards climax. "recalling memories" part is the ending of the story, and at last it is "the final" part of the story part. The development of the whole story and the arrangement of the plots are using the ingle-line progressive structural mode, with both head and tail of the story, clear structures and lines and all linked with one another.

\section{B. The Deep and Well-Rounded Character Images}

It is generally acknowledged that if narrative literature lacks in characters with distinctive personalities, the work will lose its attraction and its value of existence. Therefore, during the process of writing narrative literature, shaping typical character images has always been regarded as a core part. The reason why long narrative poems are very popular with folks is that the character images in the story are closed to people themselves in real life and are more typical, not because they are single-structured. Normally, when writers shape a character, they will stand it out without restraint, use the environment to render, and delicately describe the psychology of the character. However, long folk narrative poems usually contrast with various things in life, and construct tortuous and touching story plots by concise and powerful narrative methods, to shape well-rounded images of characters. ${ }^{(9)}$ By contrast, long Tibetan folk narrative poems of Gansu also have the same characteristics mentioned above. Writers will make use of the most beautiful things and elements in daily life to shape typical character images, such as Nima Cairang, Dasang Zhuoma, Ganjia Gama, Mancang Caiji, Najie Cailuo, Yari Asuo, Kaji Jialuo, Angla Sangjie, etc. Those are all character images with ethnic characteristics and permanent charm.

\section{The Concise and Lively Form of Language}

Generally speaking, the language of Tibetan long narrative folk poems in Gansu are bright and beautiful, simple and refined. As a vocally created and word-of-mouth civil narrative literary form with verse alternating with prose, combining speaking \& singing and complementing each other are the most unique expression form of Tibetan long folk narrative poems. This form of expression is also the most popular form among Tibetan people. Most of folk artists often use this form, to narrate with simple, vivid, and expressive languages, and to sing exquisite poems at the same time, complementing the narrative and singing. That makes stories more vivid, the languages simple but not crude, and singing more attractive to audience.

\section{CONCLUSION}

Since the end of last century, due to the continuous improvement of the awareness of cultural protection throughout the entire society, relevant departments and cultural people in Tibetan areas have successively collected, collated, translated and published books about Tibetan long folk narrative poems. However, during the interview, the author has known that some long narrative poems in remote places are still existing among folk, and those local famous poems and their existing space are facing the shock of social transformation. Therefore, the project of collecting and collating these precious folk narrative poems is an impending cultural project. Although the number of Tibetan long folk narrative poems is quite considerable, the study on Tibetan folk narrative poems does not tend to be systematized and still remains in basic or fragmented research stages. Therefore, we

\footnotetext{
(9) Lunzhu Wangmu. "Folk Literature of Northwestern Minorities" [M]. Lanzhou University Press. 2006:210.
} 
are calling on experts from all fields to protect and study these valuable cultural heritages by scientific methods.

\section{REFERENCES}

[1] Tong Jinhua. "Tibetan Folk Literature" [M]. Tibet Renmin Publishing House. 1991:13

[2] Nong Xueguan. "Introduction of Folk Literature" [M]. The Ethnic Publishing House. 2005:116.

[3] Lunzhu Wangmu."Folk Literature of Northwestern Minorities" [M]. Lanzhou University Press. 2006:210. 